\title{
EFFECT OF DIAMOX ON PLASMA BICARBONATE AND ON THE ELECTROLYTE BALANCE IN RELATION TO INTRA-OCULAR PRESSURE IN MAN*
}

\author{
BY \\ D. A. CAMPBELL, N. E. A. RENNER, AND EVA TONKS \\ Research Department, Birmingham and Midland Eye Hospital
}

THE primary action of Diamox is to inhibit the enzyme carbonic anhydrase, thereby arresting the formation of bicarbonate ions. This occurs in various tissues which contain the enzyme, notably the kidney, red blood cells, gastric mucosa, and uveal tissue. Its inhibitory action is immediate and highly specific (Mann and Keilin, 1940), and it has been questioned whether its effect on intra-ocular pressure is due to its local or its systemic action.

Experimental work on animals has shown that Diamox causes total inhibition of the enzyme in the uveal tissue (Green, Bocher, Calnan, and Leopold, 1955), that it reduces the bicarbonate content of the aqueous (Lee, 1955), that it diminishes the rate of formation of aqueous humour (Langham, 1955), and that it promotes a notable fall in intra-ocular pressure.

It was at first believed that these phenomena affected the secretory processes of the eye as described by Friedenwald (1949), but in an able summary of the evidence Duke-Elder (1957) has shown that this cannot be true. Thus, in rabbits, although the activity of carbonic anhydrase is undoubtedly inhibited in the eye by Diamox, the bicarbonate content of the aqueous is merely diminished and its concentration relative to that of the plasma remains unchanged, both being reduced (Green and others, 1955; DukeElder, Perkins and Langham, 1956). In rabbits it has been recorded that, although the carbonic anhydrase may be wholly inhibited in the eye after the intravenous or subconjunctival administration of Diamox, there may be no fall in intra-ocular pressure at all (Green and others, 1955).

Aqueous flow is reduced by some 25 per cent. when Diamox is given systemically (Langham and Lee, 1957), but a similar reduction can be achieved by the administration of ammonium chloride, a substance which like Diamox causes an acidosis, but has no effect on carbonic anhydrase (Langham and Lee, 1955).

The permeability of the blood-aqueous barrier is also unaffected by Diamox as measured by the fluorescein technique (Langham and Lee, 1957), by the transference of radioactive or non-radioactive sodium, and by the rate of transference of ascorbic acid (Langham and Lee, 1955).

The available evidence of what takes place in the human subject, which is sparse owing to the obvious difficulty of obtaining in vivo samples of aqueous,

* Received for publication June 16, 1958. 
differs slightly from the findings from animals. Franceschetti, Marty, and Dubler (1956) have reported a slight decrease in the $\mathrm{CO}_{2}$ content of the aqueous humour after the administration of Diamox, and Becker (1957), in samples taken from human subjects affected with senile cataract after 24 hours' systemic treatment with Diamox, found that the average fall in bicarbonate was much less in the aqueous $(21.5$ to $19.2 \mathrm{~m} . \mathrm{mol} . / \mathrm{kg}$.) than in the concurrent samples of arterial plasma ( 25.9 to $20.5 \mathrm{~m} . \mathrm{mol} . / \mathrm{kg}$.).

In a comparative study of the $\mathrm{CO}_{2}$ content of ocular fluids, Davson and Luck (1956) have shown that a high concentration of bicarbonate is not a general feature of mammalian aqueous humour, and have concluded that "it is unsafe to base a general theory as to the mechanism of formation of this fluid on a single feature of the chemical composition of the rabbit's aqueous humour. Indeed the action of Diamox is most pronounced in the human eye which has a deficiency of bicarbonate".

The observations which we record in this paper concerning bicarbonate of the plasma were made in the course of determining the effect of Diamox on the electrolyte balance of the blood. They provide further evidence that the variations in intra-ocular pressure are not directly associated with the changes in bicarbonate.

\section{Experimental Method}

Our experiments, which were confined as formerly (Campbell, Tonks, and Jones, 1956), to the effect of a single dose of $250 \mathrm{mg}$. Diamox, were made on ten individuals chosen at random from the glaucoma clinic.

These subjects were investigated as in-patients in a resting state, and preliminary records were made for several days of the diurnal variation of intra-ocular pressure and of blood electrolytes. The subjects were maintained on an ordinary hospital diet, with a sodium intake limited to $40-45 \mathrm{mEq}$. a day, and a state of steady hydration was maintained during the first few hours of the experiment, $140 \mathrm{ml}$. water being given at hourly intervals 2 hours before and 3 hours after the dose of Diamox. In short, the sodium and fluid intakes were limited so as not to influence the blood changes. Samples of blood were taken by venepuncture, under paraffin.

Methods of Estimation.-In the course of our investigations, the following methods of estimation were used:

\begin{tabular}{|c|c|c|c|}
\hline Serum sodium & $\cdots$ & .. & .. Flame photometer \\
\hline Serum potassium & . & . & . Flame photometer \\
\hline Serum calcium & . & . & .. Kramer and Tisdall (1921) \\
\hline Serum magnesium .. & . & . & .. Briggs (1922a) \\
\hline Serum chloride $\quad .$. & $\ldots$ & .. & .. Claudius (1922) \\
\hline Serum phosphorus . : & . & . & .. Briggs (1922b) \\
\hline Serum inorganic sulphate & . & . & .. Letonoff and Reinhold (1936) \\
\hline Serum protein & . & . & .. Wolfson, Cohn, Calvary, and Ichiba (1948) \\
\hline Serum bicarbonate .. & . & . & $\begin{array}{l}\text {. Manometric method using the Warburg } \\
\text { apparatus }\end{array}$ \\
\hline Serum organic acid .. & . & . & .. Deduced by subtraction \\
\hline
\end{tabular}




\section{Results}

(1) Plasma Bicarbonate.-The concurrent changes in plasma bicarbonate and in intra-ocular pressure in each of the ten subjects are shown in the Table. The bicarbonate fell slowly in the first few hours after the administration of Diamox, and showed comparatively little change during the period of maximum fall in intra-ocular pressure. The pressure returned to its original level within 24 hours, and the usual diurnal variations were resumed in the subsequent days (Fig. 1, overleaf), while the plasma bicarbonate continued to fall.

The figures for individual cases (Fig. 2, overleaf) show that in some cases the plasma bicarbonate did not return to its predosage level for 6 days.

(2) Electrolyte Balance.-The total electrolyte balance was followed in two subjects ( 9 and 10) before and after the administration of Diamox. Similar results were obtained, Case 9 being affected with open-angle glaucoma with no field loss and no cupping of the optic discs, while Case 10 suffered from narrow-angle glaucoma, bilateral cupping of the discs, and marked loss of visual field in both eyes. The data given in Fig. 3 (overleaf) refer to Case 9. There was an immediate fall in the total cations, mainly because of a fall in sodium, which remained below the initial level for 48 hours. The fall in

TABLE : EFFECT OF DIAMOX ON $\mathrm{CO}_{2}$ OF PLASMG

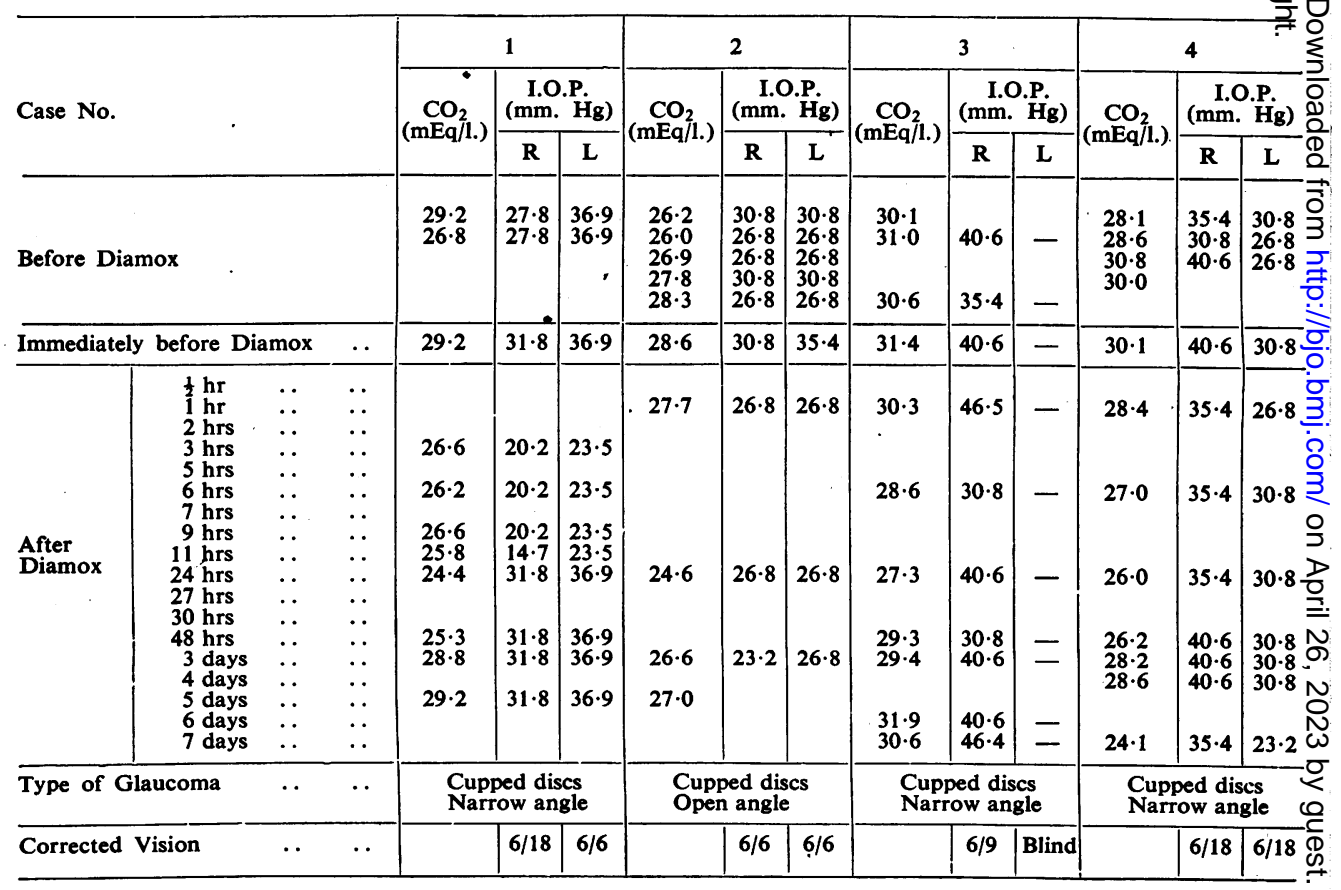


potassium was proportionately greater than that in sodium, but was not sustained.

A similar fall took place in the total anions, mainly because of the fall in chloride and bicarbonate, of which the former contributed 50 per cent. and the latter approximately 20 per cent. during the first 2 hours. At the end of 5 hours the chloride rose in compensation for the continued fall of bicarbonate. Plasma protein did not begin to fall until after this time.

Although the proportionate fall in ions as displayed graphically in Fig. 3 is a little misleading owing to differences in scale, it is evident that sodium and chloride are the ions most affected during the first 6 hours after Diamox, i.e. during the fall in intra-ocular pressure, and that the fall in bicarbonate during this time is not significant.

\section{Discussion}

Our findings show that there is no direct association between the small reduction in plasma bicarbonate and the immediate fall in intra-ocular pressure which occurs after the administration of Diamox. Moreover the intra-ocular pressure appears to behave independently of a low level of plasma bicarbonate for several days. It is more probable that the ocular effect of the drug is associated with some other aspect of its systemic action, bearing in mind that in continuous therapy the self-limiting effect of Diamox is

AND ON INTRA-OCULAR PRESSURE IN TEN CASES

\begin{tabular}{|c|c|c|c|c|c|c|c|c|c|c|c|c|c|c|c|c|c|}
\hline \multicolumn{3}{|c|}{5} & \multicolumn{3}{|c|}{6} & \multicolumn{3}{|c|}{7} & \multicolumn{3}{|c|}{8} & \multicolumn{3}{|c|}{9} & \multicolumn{3}{|c|}{10} \\
\hline \multirow{2}{*}{$\underset{(\mathrm{mEq} / \mathrm{l} .)}{\mathrm{CO}_{2}}$} & \multicolumn{2}{|c|}{$\begin{array}{c}\text { I.O.P. } \\
(\mathrm{mm} . \mathrm{Hg})\end{array}$} & \multirow{2}{*}{$\underset{(\mathrm{mEq} / \mathrm{l} .)}{\mathrm{CO}_{2}}$} & \multicolumn{2}{|c|}{$\begin{array}{c}\text { I.O.P. } \\
\text { (mm. Hg) }\end{array}$} & \multirow{2}{*}{$(\mathrm{mEq} / 1)}$. & \multicolumn{2}{|c|}{$\begin{array}{c}\text { I.O.P. } \\
(\mathrm{mm} . \mathrm{Hg})\end{array}$} & \multirow{2}{*}{$\frac{\mathrm{CO}_{2}}{(\mathrm{mEq} / 1 .)}$} & \multicolumn{2}{|c|}{$\begin{array}{c}\text { I.O.P. } \\
\text { (mm. Hg) }\end{array}$} & \multirow{2}{*}{$\begin{array}{c}\mathrm{CO}_{2} \\
(\mathrm{mEq} / 1 .)\end{array}$} & \multicolumn{2}{|c|}{$\begin{array}{l}\text { I.O.P. } \\
(\mathrm{mm} . \mathrm{Hg})\end{array}$} & \multirow{2}{*}{$\begin{array}{c}\mathrm{CO}_{2} \\
(\mathrm{mEq} / \mathrm{l} .)\end{array}$} & \multicolumn{2}{|c|}{$\begin{array}{l}\text { I.O.P. } \\
(\mathrm{mm} . \mathrm{Hg})\end{array}$} \\
\hline & $\mathbf{R}$ & $\mathbf{L}$ & & $\mathbf{R}$ & L & & $\mathbf{R}$ & $\mathbf{L}$ & & $\mathbf{R}$ & $\mathbf{L}$ & & $\mathbf{R}$ & $\mathbf{L}$ & & $\mathbf{R}$ & L \\
\hline $\begin{array}{l}28 \cdot 5 \\
27 \cdot 0 \\
28 \cdot 5 \\
26 \cdot 5\end{array}$ & $\begin{array}{l}31.8 \\
36.9 \\
36.9\end{array}$ & $\begin{array}{r}27 \cdot 4 \\
31 \cdot 8 \\
31 \cdot 8\end{array}$ & $\begin{array}{l}28 \cdot 6 \\
30 \cdot 8 \\
\end{array}$ & $\begin{array}{l}14 \cdot 7 \\
12 \cdot 5 \\
\end{array}$ & $\begin{array}{l}14 \cdot 7 \\
12 \cdot 5\end{array}$ & $\begin{array}{l}30.6 \\
29 \cdot 8 \\
29.4\end{array}$ & $\begin{array}{l}20 \cdot 2 \\
20 \cdot 2 \\
23 \cdot 5\end{array}$ & $\begin{array}{l}23 \cdot 5 \\
23 \cdot 5 \\
27 \cdot 4\end{array}$ & $\begin{array}{l}31 \cdot 0 \\
29 \cdot 1 \\
31 \cdot 4\end{array}$ & $\begin{array}{l}23 \cdot 5 \\
27 \cdot 4 \\
27 \cdot 4\end{array}$ & $\begin{array}{l}27 \cdot 4 \\
27 \cdot 4 \\
27 \cdot 4\end{array}$ & $\begin{array}{l}30 \cdot 6 \\
30 \cdot 3\end{array}$ & $20 \cdot 2$ & $27 \cdot 4$ & $\begin{array}{l}30 \cdot 8 \\
29 \cdot 4\end{array}$ & $\begin{array}{l}46.5 \\
40.6\end{array}$ & $\begin{array}{l}14 \cdot 7 \\
10 \cdot 7\end{array}$ \\
\hline $28 \cdot 1$ & $27 \cdot 4$ & $23 \cdot 5$ & $30 \cdot 2$ & $12 \cdot 5$ & $12 \cdot 5$ & $31 \cdot 0$ & $27 \cdot 4$ & $23 \cdot 5$ & $30 \cdot 3$ & $27 \cdot 4$ & $23 \cdot 5$ & $31 \cdot 0$ & $31 \cdot 8$ & $27 \cdot 4$ & $31 \cdot 0$ & $46 \cdot 5$ & $17 \cdot 2$ \\
\hline $27 \cdot 2$ & $31 \cdot 8$ & $20 \cdot 2$ & $29 \cdot 3$ & $12 \cdot 5$ & $12 \cdot 5$ & $30 \cdot 1$ & 36.9 & $23 \cdot 5$ & $\begin{array}{l}30 \cdot 5 \\
28 \cdot 6\end{array}$ & $\begin{array}{l}17 \cdot 3 \\
23 \cdot 5\end{array} \mid$ & $\begin{array}{l}20 \cdot 2 \\
23 \cdot 5\end{array}$ & $\begin{array}{c}29 \cdot 7 \\
29 \cdot 4 \\
29 \cdot 2 \\
28 \cdot 4 \\
26 \cdot 0\end{array}$ & $\begin{array}{l}27 \cdot 4 \\
27 \cdot 4 \\
27 \cdot 4 \\
20 \cdot 2 \\
20 \cdot 2\end{array}$ & $\begin{array}{l}23 \cdot 5 \\
23 \cdot 5 \\
23 \cdot 5 \\
20 \cdot 2 \\
20 \cdot 2\end{array}$ & $\begin{array}{l}28 \cdot 5 \\
31 \cdot 1 \\
31 \cdot 0 \\
31 \cdot 1 \\
28 \cdot 0\end{array}$ & $\begin{array}{l}46.5 \\
40.6 \\
35.4 \\
35 \cdot 4 \\
35 \cdot 4\end{array}$ & $\begin{array}{r}17 \cdot 2 \\
12 \cdot 6 \\
12 \cdot 6 \\
14 \cdot 7 \\
14 \cdot 7\end{array}$ \\
\hline $24 \cdot 8$ & $27 \cdot 4$ & $23 \cdot 5$ & $28 \cdot 1$ & $17 \cdot 3$ & $14 \cdot 7$ & $27 \cdot 4$ & 23.5 & $23 \cdot 5$ & $\begin{array}{l}27 \cdot 3 \\
26 \cdot 2 \\
28 \cdot 2\end{array}$ & $\begin{array}{l}27 \cdot 4 \\
27 \cdot 4 \\
27 \cdot 4\end{array}$ & $\begin{array}{l}23 \cdot 5 \\
27 \cdot 4 \\
27 \cdot 4\end{array}$ & $27 \cdot 0$ & $27 \cdot 4$ & $27 \cdot 4$ & $27 \cdot 0$ & $40 \cdot 6$ & $12 \cdot 6$ \\
\hline $\begin{array}{l}24 \cdot 9 \\
26 \cdot 0\end{array}$ & $\begin{array}{l}31 \cdot 8 \\
31 \cdot 8\end{array}$ & $\begin{array}{l}23 \cdot 5 \\
27 \cdot 4\end{array}$ & $31 \cdot 0$ & $14 \cdot 7$ & $14 \cdot 7$ & $\begin{array}{l}26 \cdot 7 \\
28 \cdot 6\end{array}$ & $20 \cdot 2$ & $23 \cdot 5$ & & & & $\begin{array}{l}27 \cdot 9 \\
28 \cdot 6\end{array}$ & $27 \cdot 4$ & $27 \cdot 4$ & $32 \cdot 5$ & $46 \cdot 5$ & $17 \cdot 3$ \\
\hline $29 \cdot 7$ & & & & & & $29 \cdot 4$ & & & & & & $30 \cdot 8$ & & & & & \\
\hline \multicolumn{3}{|c|}{$\begin{array}{l}\text { Cupped discs } \\
\text { Narrow angle }\end{array}$} & \multicolumn{3}{|c|}{$\begin{array}{l}\text { Cupped discs } \\
\text { Narrow angle }\end{array}$} & \multicolumn{3}{|c|}{$\begin{array}{l}\text { Normal discs } \\
\text { Narrow angle }\end{array}$} & \multicolumn{3}{|c|}{$\begin{array}{l}\text { Cupped discs } \\
\text { Narrow angle }\end{array}$} & \multicolumn{3}{|c|}{$\begin{array}{l}\text { Left disc cupped } \\
\text { Open angle }\end{array}$} & \multicolumn{3}{|c|}{$\begin{array}{l}\text { Cupped discs } \\
\text { Narrow angle }\end{array}$} \\
\hline & $6 / 18$ & $6 / 24$ & & $6 / 6$ & $6 / 6$ & & $6 / 9$ & $6 / 9$ & & $6 / 6$ & $6 / 6$ & & $6 / 9$ & $6 / 9$ & & $6 / 12$ & $6 / 9$ \\
\hline
\end{tabular}



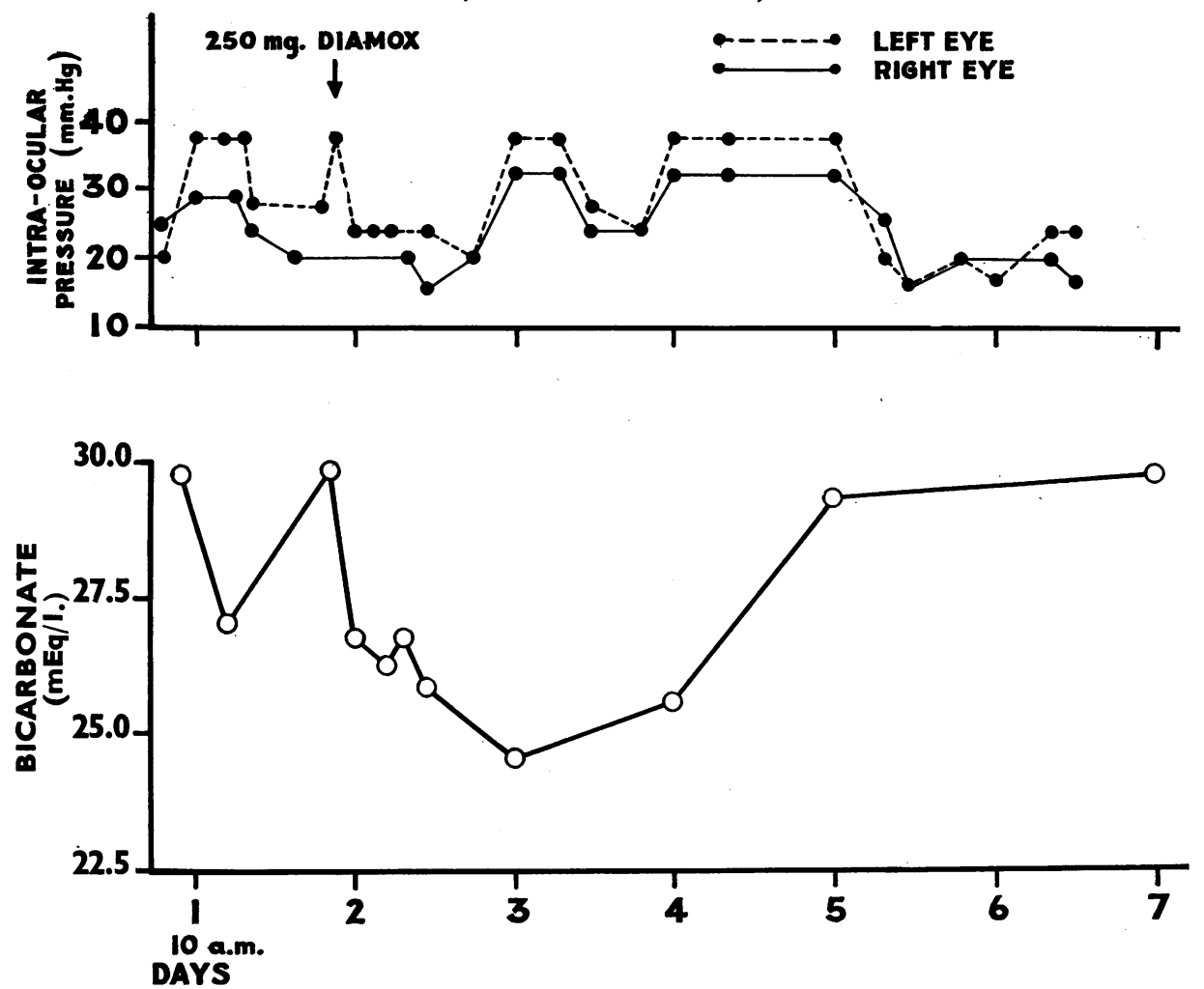

Fig. 1.-Plasma bicarbonate and intra-ocular pressure after oral administration of $250 \mathrm{mg}$. Diamox in a case of narrow-angle glaucoma.

determined by the fall in plasma bicarbonate (Counihan, Evans, and Milner, 1954; Schwartz and Relman, 1954). In fact, the fall in intra-ocular pressure is more closely associated with the fall in sodium, potassium, and chloride ions and with the concurrent increase in excretion of these ions.

Sodium in particular is intimately linked with the transference of water within the body and with its excretion. Neither the diuresis nor the naturesis which occur after Diamox can, however, explain its effect on the eye, for other diuretics such as chorothiazide, mictine, or the mercurials which also promote sodium excretion have no effect on the intra-ocular pressure (authors' unpublished work).

Neither are the aspects of chloride metabolism during Diamox therapy fully understood. According to our findings, the chloride concentration of the blood falls during the first few hours and then rises. This hyperchloraemic acidosis is compensatory for the loss of bicarbonate from the blood and is said to be due to a contraction of the extra-cellular fluid volume. Hyperchloraemia continues during prolonged Diamox therapy without change in the external chloride balance (Leaf, Schwartz, and Relman, 1954; Counihan and others, 1954; Maren, Wadsworth, Yale, and Alonzo, 1954). When the body is in this state the eye shews a steady decline in its 

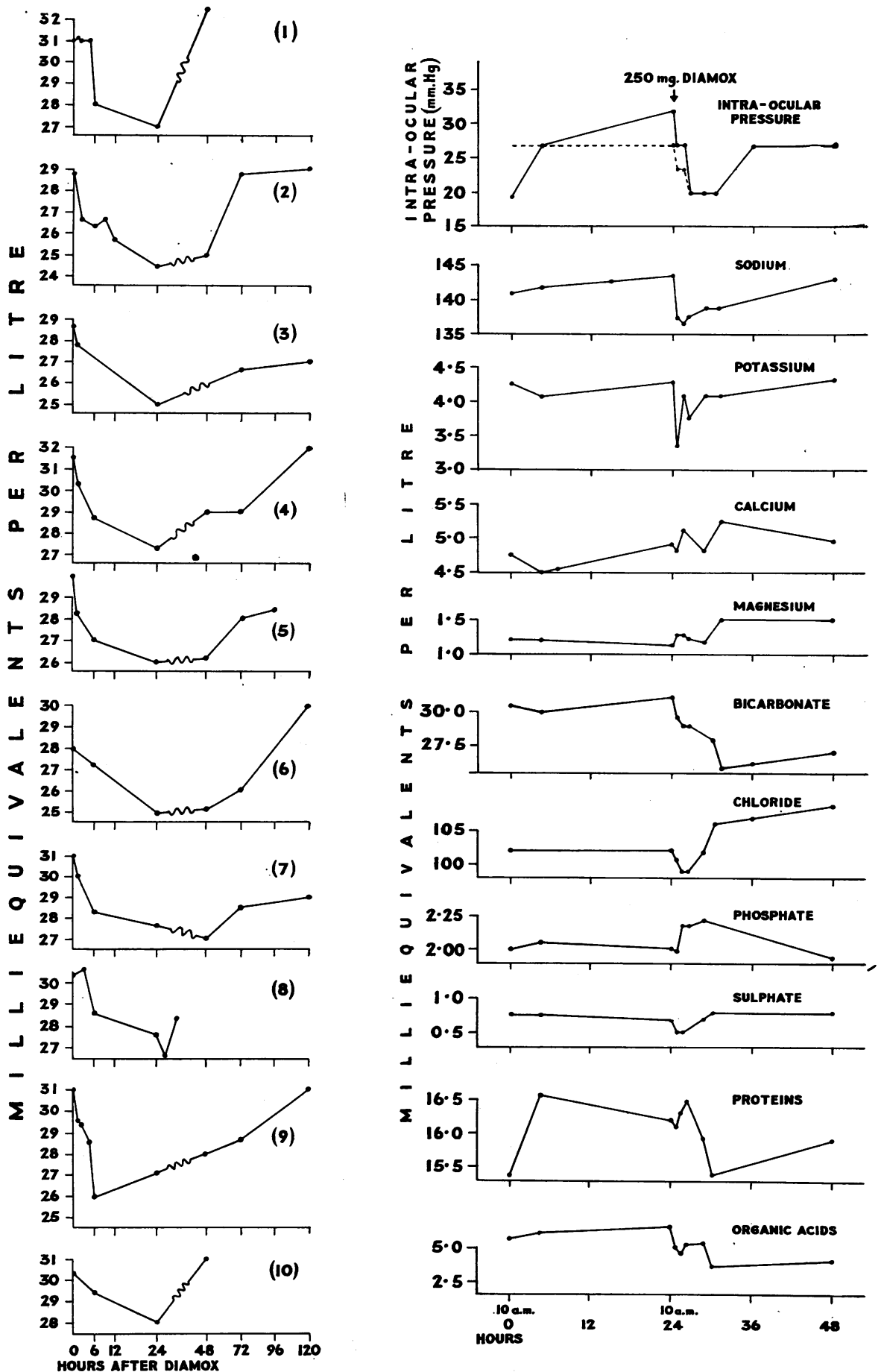

$+$
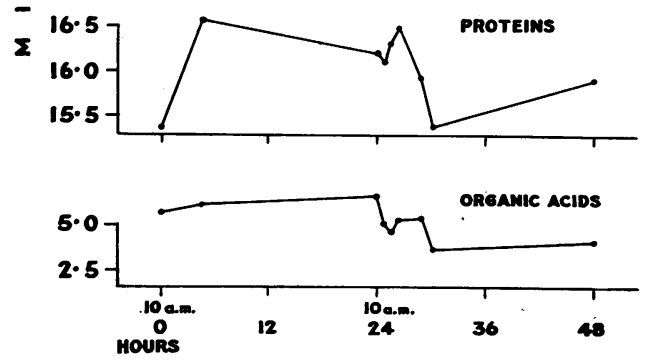

FIG. 2.-Plasma bicarbonate in ten glaucomatous subjects after oral administration of $250 \mathrm{mg}$. Diamox.

Fig. 3.-Intra-ocular pressure and electrolyte balance in Case 9, before and after oral administration of $250 \mathrm{mg}$. Diamox. 
response to repeated doses of Diamox (Campbell and others, 1956), and in practice the response can be restored by giving potassium bicarbonate (Campbell, Jones, Renner and Tonks, 1957).

Again, if a state of acidosis and hyperchloraemia is engendered before the administration of Diamox, the urinary changes are absent or minimal (Kaye, 1955), and in the few experiments in which we have given ammonium chloride for 24 hours before Diamox the expected fall in intra-ocular pressure has not occurred. Further investigation is needed of the significance of chloride metabolism in relation to intra-ocular pressure. It is an interesting fact that massive oedema cannot be removed from the body unless the excretion of chloride is provoked as well as the excretion of sodium (Lancet, 1955), and it may well be that a similar combination of factors is essential for the lowering of intra-ocular pressure by osmotic means.

\section{Conclusions}

(1) The immediate reduction in plasma bicarbonate after the administration of Diamox is so slight as to suggest that it bears no direct relationship to the concurrent fall in intra-ocular pressure.

(2) A study of the electrolyte balance shows that after the administration of Diamox the fall in sodium and chloride is probably more significant than that of the other ions in relation to intra-ocular pressure.

\section{REFERENCES}

BeCKer, B. (1957). A.M.A. Arch. Ophthal., 57, 793.

Briggs, A. P. (1922a). J. biol. Chem., 52, 349. (1922b). Ibid., 53, 13.

Campbell, D. A., Jones, M., Renner, N. E. A., and Tonks, E. L. (1957). Brit. J. Ophthal., 41, 746.

, Tonks, E. L., and Jones, M. (1956). Ibid., 40, 283.

Claudius, D. (1922). "Verhand. 34 Kongr. Dsch. Ges. inn. Med. Wiesbaden”, p. 138.

Counihan, T. B., Evans, B. M., and Milne, M. D. (1954). Clin. Sci., 13, 583.

Davson, H., and LuCK, C. P. (1956). J. Physiol. (Lond.), 132, 454.

DUKE-ELDER, S. (1957). Trans. ophthal. Soc. U.K., 77, 205.

- Perkins, E. S., and Langham, M. E. (1956). Arch. Soc. oftal. hisp.-amer., 16, 259.

FranCESCHETTI, A., MARTY, F., and DUbleR, H. (1956). "International Symposium on Aqueous Humour, Munich, May 14-15, 1956".

Friedenwald, J. S. (1949). Amer. J. Ophthal., 32, June, Part II, p. 9.

Green, H., Bocher, C. A., Calnan, A. F., and Leopold, I. H. (1955). A.M.A. Arch. Ophthal., $53,463$.

KAYE, M. (1955). J. clin. Invest., 34, 277.

Kramer, B., and Tisdall, F. F. (1921). J. biol. Chem., 47, 475.

Lancet (1955). "Review on Diuresis from Carbonic Anhydrase Inhibition", 1, 706.

LANGHAM, M. E. (1955). J. Physiol. (Lond.), 128, 78P. and LeE, P. M. (1955). Ibid., 130, 27P.

- (1957). Brit.J. Ophthal., 41, 65.

Leaf, A., Schwartz, W. B., and Relman, A. S. (1954). New Engl.J. Med., 250, 759.

LEe, P. M. (1955). J. Physiol. (Lond.), 128, 80P.

Letonoff, T. Y., and Reinhold, J. G. (1936). J. biol. Chem., 114, 147.

MANN, T., and KeILIN, D. (1940). Nature (Lond.), 146, 164.

Maren, T.H., Wadsworth, B. C., Yale, E. K., and Alonso, L. G. (1954). Bull. Johns Hopk. Hosp., 95, 277.

Schwartz, W. B., and Relman, A. S. (1954). J. clin. Invest., 33, 965.

TisDall, F. F. (1923). J. biol. Chem., 56, 439.

Wolfson, W. Q., Cohn, C., Calvary, E., and Ichiba, F. (1948). Amer. J. clin. Path., 18, 723. 